\author{
NATAlia NOWAK ${ }^{1}$, PAWEŁ POMORSKI ${ }^{2,3}$ \\ ${ }^{1}$ Pracownia Obrazowania Struktury i Funkcji Tkankowych \\ Centrum Neurobiologii \\ Instytut Biologii Doświadczalnej im. M. Nenckiego PAN \\ ${ }^{2}$ Pracownia Molekularnych Podstaw Ruchów Komórkowych \\ Zakład Biochemii \\ Instytut Biologii Doświadczalnej im. M. Nenckiego PAN \\ ${ }^{3}$ Środowiskowe Multimodalne Laboratorium Adhezji i Ruchu Komórek \\ Instytut Biologii Doświadczalnej im. M. Nenckiego PAN \\ Pasteura 3, 02-093 Warszawa \\ E-mail:p.pomorski@nencki.gov.pl
}

\title{
MIKROSKOPOWE METODY BADANIA CYTOSZKIELETU
}

\section{WPROWADZENIE}

Termin cytoszkielet, jak wiele innych terminów zbiorczych, jest równie oczywisty, co nieprecyzyjny. $Z$ jednej strony, oczywiste jest, że cytoszkielet tworzą włókna białkowe, odpowiedzialne za utrzymywanie kształtu komórki, mniej oczywiste jest, które $z$ białek zwiazanych $z$ nimi, zaliczymy do białek cytoszkieletalnych. W latach 80. XX w. powstała definicja funkcjonalna cytoszkieletu mówiąca, że jest to "wewnątrzkomórkowa sieć włókien białkowych nierozpuszczająca się w detergentach niejonowych" (ANDERSEN i współaut. 1991). Ta definicja, jakże wygodna $z$ punktu widzenia biochemii, zalicza do cytoszkieletu także wszystkie białka, które towarzysza tworzącym go włóknom białkowym. Cytoszkielet tworza zatem podstawowe białka polimeryzujące $\mathrm{w}$ filamenty czy sieci: aktyna, tubulina, białka włókien pośrednich czy specyficzne komórkowo białka, takie jak spektryna, oraz tysiące innych cząsteczek: białek regulatorowych, motorów molekularnych, białek adaptorowych czy też białek uczestniczaccych w przekazywaniu sygnałów. Tak złożona struktura białkowa, o tak dobrze zdefiniowanej formie przestrzennej, jest wymarzonym obiektem do badań mikroskopowych i mikroskopia towarzyszy studiom nad cytoszkieletem od ich zarania. Postaramy się tu opisać podstawowe metody mikroskopowe, które każdy badacz struktury i funkcji cytoszkieletu powinien znać. Zarysujemy też tło historyczne ich rozwoju i wykażemy, że badania nad cytoszkieletem odegrały niebagatelna rolę w rozwoju tych metod.

\section{METODY STRUKTURALNE}

\section{METODY ZNAKOWANIA CYTOSZKIELETU W UTRWALONYCH KOMÓRKACH I TKANKACH \\ Mikroskopia fluorescencyjna i przełom w badaniach strukturalnych komórki}

Wraz $z$ rozwojem metod biochemii i genetyki molekularnej, biologia oddalała się od modelu nauki obserwacyjno-opisowej i stawała się nauka eksperymentalna. Towarzyszyła temu utrata znaczenia tradycyjnej mikroskopii optycznej, której rozdzielczość była niedostateczna do bezpośredniej obserwacji badanych struktur, a specyficzność dostępnych wówczas barwień dalece niewystarczajaca. Jednocześnie, od połowy XIX w. znana była niezwykle czuła metoda barwienia, jaka jest barwienie fluorescencyjne. Ponieważ barwnik fluorescencyjny emituje, a nie pochłania, światło możemy wykryć znacznie mniejsze jego stężenia. Już na początku XX w. pojawily się pierwsze mikroskopy fluorescencyjne. Problemem było jednak wzbudzanie fluorescencji. W tym celu należało oświetlić obserwowany obiekt światłem wzbudzajacym, które w tradycyjnym mikroskopie

Słowa kluczowe: cytoszkielet, immunocytochemia, mikroskopia elektronowa, mikroskopia optyczna, mikroskopia superrozdzielcza, sondy molekularne 
optycznym oślepia obserwatora. Problem ten został częściowo rozwiazany w latach 20. wraz ze skonstruowaniem mikroskopu epifluorescencyjnego (ELLINGER i HIRT 1929). Epifluorescencja (od greckiego єпі oznaczającego „na”) polega na wprowadzeniu światła wzbudzajaccego przez obiektyw za pomoca półprzepuszczalnego lustra wstawionego w droge optyczna mikroskopu. Taka konstrukcja ma dwie ogromne zalety: po pierwsze, światło wzbudzajace nie wnika bezpośrednio w szlak obserwacyjny mikroskopu. Po drugie, obiektyw stanowi jednocześnie kondensor dla światła wzbudzającego i znajduje się $z$ definicji $w$ idealnej pozycji. W momencie powstania tej konstrukcji, problemy $z$ technologia produkcji filtrów powodowały jednak, że nawet niewielka ilość światła wzbudzającego, która odbijała się od preparatu lub zostawała w nim rozproszona, wciąż mogła być jaśniejsza od światła emitowanego przez preparat i tylko bardzo jasne barwienia mogły być obserwowane. Techniki mikroskopii fluorescencyjnej wymagały jeszcze pół wieku rozwoju, by w latach 70 . dorównać precyzja molekularnym technikom in vitro. Jednym $z$ podstawowych powodów tego stanu rzeczy był problem $z$ wydajna filtracja światła $i$ dopiero rozwój filtrów interferencyjnych, dostępnych od lat 70 . w racjonalnych cenach, umożliwił rozwój mikroskopii fluorescencyjnej jaka znamy dziś (Ryc. 1).

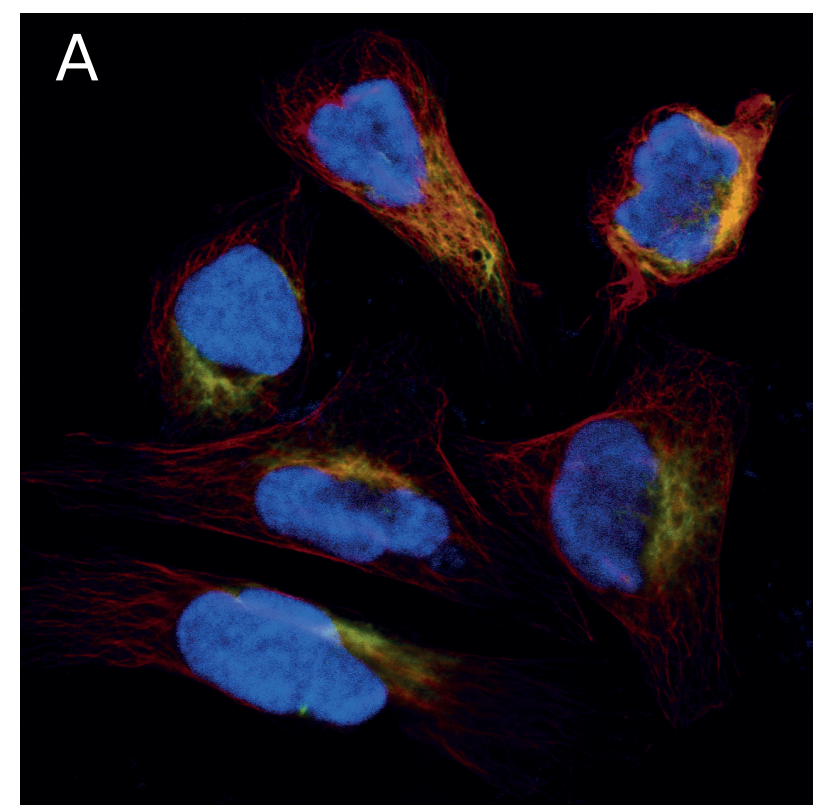

Znakowanie białek cytoszkieletu przeciwciałami

Wydajne barwienie preparatów biologicznych nie zapewniało wystarczajacej specyficzności, pozwalając barwić chemicznie całe klasy związków, ale nie precyzyjnie znakować konkretne białka. Istnieje jednak w naturze klasa cząsteczek, która pozwala precyzyjnie wykrywać specyficzne, przestrzenne struktury molekularne białek czy wielocukrów, zwane epitopami. Sa to przeciwciała. Organizm kręgowca może produkować miriady rodzajów przeciwciał, wykrywających praktycznie wszystkie możliwe białka występujące w przyrodzie. Pierwsze zastosowanie przeciwcial jako specyficznego znacznika w mikroskopii nastapiło już w latach 40. XX w. Wtedy to stworzono niezwykle czuła metodę wykrywania pneumokoków przy pomocy przeciwciał sprzężonych $z$ barwnikiem fluorescencyjnym, skierowanych przeciwko białkom powierzchniowym tych bakterii (CoONs i współaut. 1942). Była to wówczas jednak bardziej metoda diagnostyczna niż sposób obrazowania. $\mathrm{Na}$ pierwsze prace pokazujące przestrzenne obrazy cytoszkieletu znakowanego przeciwciałami trzeba było czekać do 1974 r. (LAZARIDES i WEBER 1974), gdy autorzy pokazali filamenty aktynowe w fibroblastach linii 3T3 i w komórkach zarodków kurczaka.

Podczas gdy do znakowania włókien cytoszkieletu wystarczajace było wykorzystanie mieszaniny przeciwciał izolowanych $z$

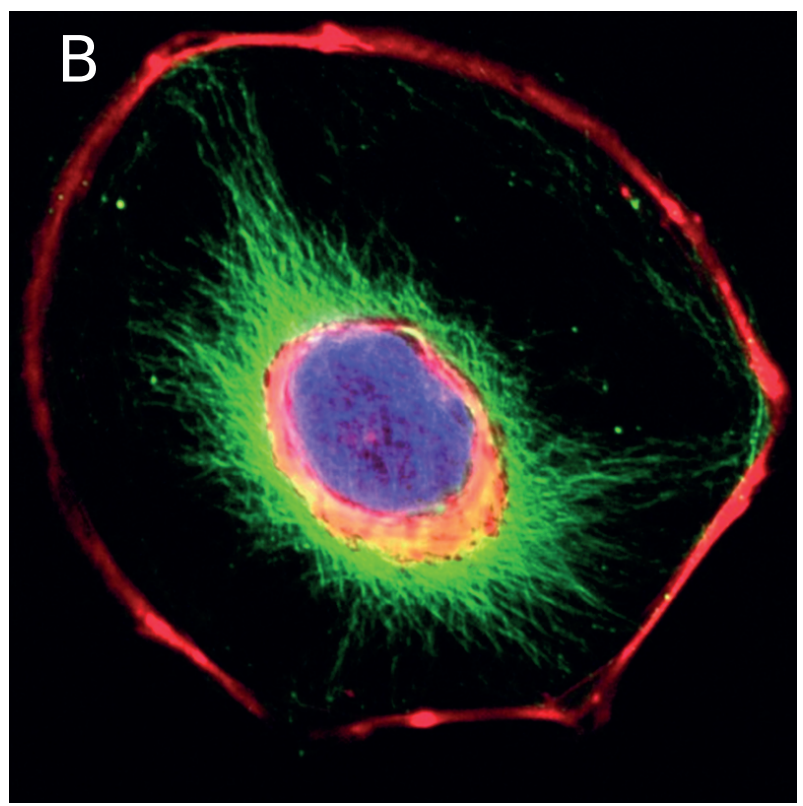

Ryc. 1. Fluorescencyjne obrazowanie cytoszkieletu w komórce.

A. Komórki linii U-2 OS kostniakomięsaka człowieka; czerwono znakowana przeciwciałami tubulina, zielono znakowane przeciwciałami włókna pośrednie (nestyna), na niebiesko znakowano jądro komórkowe (DAPI). Obraz z Human Protein Atlas (HPA). B. Fibroblast 3T3 kurczaka; czerwono znakowana falloidyna aktyna, zielono znakowane włókna pośrednie, niebiesko znakowane jądro komórkowe (DAPI), ze zbiorów Wellcome Images Project. Oba obrazy pobrano z Cell Image Library, prowadzonej przez Amerykańskie Towarzystwo Biologii Komórki. Obrazy udostępnione na licencji Creative Commons. 
osocza immunizowanych białkami cytoszkieletu zwierząt (głównie królików), to znakowanie białek inkrustujących te włókna stało się znacznie bardziej specyficzne wraz $z$ wprowadzeniem przeciwciał monoklonalnych. Teoria selekcji klonalnej w układzie odpornościowym (BURNET 1976) wskazywała, że powinno być możliwe wyizolowanie grupy komórek, produkujacej przeciwciała odpowiadajace tylko na jeden, wybrany epitop, czyli niewielki fragment białka mogacy wiązać przeciwciało. Już wcześniej, takie pojedyncze klony były izolowane i namnażane w myszach pozbawionych układu odpornościowego (AsKONAS i współaut. 1970), ale dopiero $\mathrm{w}$ połowie lat 70 . opracowano technikę hybrydyzacji limfocytów B z komórkami szpiczaka, w celu uzyskania trwałego źródła przeciwciał o ściśle zdefiniowanej specyficzności (KÖHLER i MILstein 1975). Co ciekawe, autorzy tej publikacji mieli poważne problemy $z$ powtórzeniem swych prac po przeniesieniu doświadczeń w potencjalnie znacznie lepsze warunki. Problemy były tak znaczne, że Milstein był bliski wycofania pracy $\mathrm{z} \mathrm{Na}-$ ture, szczęśliwie Giovanni Galfré znalazł źródło problemów w pożywce, na której hodowano komórki i zoptymalizował proces fuzji (GALFRE i MiLSTEIN 1981). W 1984 r. autorzy pracy otrzymali za swoje badania nagrodę Nobla, a dziś trudno sobie wyobrazić wspó1czesna biologię komórki bez wykorzystywania przeciwciał monoklonalnych.

Znakowanie przeciwciałami ma ogromna specyficzność i pozwala zidentyfikować nie tylko białka, ale nawet ich stan fizjologiczny (np. to czy sa ufosforylowane w określonym miejscu czy nie). Niestety rozdzielczość mikroskopu optycznego jest niewspółmiernie duża do rozmiarów cząsteczek białka, a to, że znakowane białka znajdujemy w tym samym miejscu na mikrofotografii nie znaczy, że tworza one kompleks. Aby przekonać się, że obiekty znakowane przeciwciałami znajduja się wystarczajaco blisko by ze soba oddziaływać, stworzono technikę zwana ligacja zbliżeniowa (ang. proximity ligation assay, PLA). Polega ona na użyciu przeciwciał znakujacych epitopy na dwóch badanych białkach, każde zwiazane $z$ połowa startera PCR. Po zwiazaniu przeciwciał, do preparatu dodaje się ligazy. Jeśli dwa fragmenty startera znajduja się od w odległości kilkudziesięciu nanometrów od siebie, ligaza przeprowadzi reakcje ligacji i powstanie kompletny starter PCR. Do roztworu dodaje się następnie kolista cząstkę jednoniciowego DNA, kompatybilna ze starterem oraz znakowane fluorescencyjnie nukleotydy i polimerazę, która prowadzi reakcję polimeryzacji DNA na dodanej kolistej matrycy. Powstaje fluorescencyjny produkt, który możemy zo- baczyć w mikroskopie jako punkt. Jeśli do ligacji nie dojdzie, połówki startera będa za krótkie i reakcja się nie rozpocznie. Pojawienie się świecacych punktów świadczy o bardzo bliskim położeniu dwóch białek i praktycznie gwarantuje, że moga one tworzyć kompleks. Metoda jest uniwersalna, ale $z$ powodzeniem bywa wykorzystywana również w badaniach nad cytoszkieletem (SCHNEIDER i współaut. 2010).

Aktyna i falloidyna, marker wyjątkowy i jego wady

Falloidyna, odkryta w latach 30. XX w., jako jedna $z$ toksyn produkowanych przez muchomora sromotnikowego Ammanita phalloides (LYNEN i WIELAND 1938), jest zwiazkiem ze wszech miar niezwykłym. Czassteczka falloidyny jest cyklicznym heptapeptydem (składa się $z$ siedmiu aminokwasów), tworzacym, dzięki mostkowi siarczkowemu łączacemu cysteinę $z$ tryptofanem, podwójny pierścień. Peptyd ten silnie wiąże się $Z$ filamentami aktyny w taki sposób, że jedna cząsteczka falloidyny trwale wiąże się $z$ trzema protomerami aktyny (informacje o budowie aktyny i filamentów aktynowych patrz REDOWICZ oraz MORACZEWSKA w tym zeszycie KOSMOSU). Fluorescencyjne znakowanie aktyny falloidyna okazało się metoda niezwykle szybka i wygodna w użyciu, barwiac tylko spolimeryzowana formę aktyny i wymagając tylko jednej, krótkiej inkubacji białka ze znacznikiem (WULF i współaut. 1979). Z czasem falloidyna stała się złotym standardem w wizualizacji mikrofilamentów. Nie można jednak zapominać, że falloidyna jest silna toksyna i nadaje się głównie do barwienia preparatów utrwalonych; falloidyna stabilizuje bowiem mikrofilamenty i blokuje uwalnianie zwiazanego $z$ aktyna ADP, co w konsekwencji uniemożliwia depolimeryzację filamentów i zaburza dynamikę cytoszkieletu (VANDEKERCKHOVE i współaut. 1985). Przyżyciowe podanie peptydu w większych stężeniach, koniecznych do wizualizacji mikrofilamentów, zmienia fizjologię komórki i ostatecznie prowadzi do jej śmierci (WEHLAND i współaut. 1977). Jeśli jednak stężenia falloidyny sa niskie, nie zakłóca ona funkcji komórki, co wykorzystano do ratiometrycznego określania stosunku F/G aktyny w komórkach Amoeba proteus, do których wstrzyknięto mieszaninę znakowanej fluorescencyjnie falloidyny i przeciwciał przeciw aktynie (POMORSKI i współaut. 2007). Metoda ta pozwalała na pokazanie stopnia polimeryzacji w różnych rejonach komórki, ale nie wizualizację struktur cytoszkieletu. Dziśs falloidyna jest powszechnie używana w badaniach biologii komórki, a nowe rozwiazania stosowane w jej syntezie (falloidyny 
nie otrzymuje się dziś $z$ grzybów) pozwalają mieć nadzieję na dalsze udoskonalanie funkcjonalności tego znacznika (ANDERSON i współaut. 2005).

Zastosowanie znakowania cytoszkieletu w mikroskopii elektronowej, mikroskopia korelacyjna

Rozdzielczość optyczna, czyli najmniejsza odległość między obiektami jaką możemy zobaczyć w tradycyjnej mikroskopii świetlnej, wynosi $200 \mathrm{~nm}$ (co jest równe mniej więcej połowie długości fali światła użytego do obrazowania). Co najmniej kilkukrotnie przewyższa ona średnice filamentów tworzących cytoszkielet. Mikroskopia elektronowa (ang. electron microscopy, EM) do uzyskania obrazu zamiast swiatła wykorzystuje wiąkę elektronów. Zgodnie $z$ teorią kwantowa, taką wiąkę możemy interpretować w świetle dualizmu korpuskularno-falowego, jako falę de Broglie'a o długości zależnej od pędu elektronów, który w mikroskopie elektronowym determinowany jest przez napieccie rozpędzające cząsteczki. Długość fali zwiąanej $z$ wiązka elektronów rozpędzonych napięciem 200.000 Voltów (o energii $200 \mathrm{keV}$ ) wynosi $2,5 \mathrm{pm}$ (pikometra, $10^{-12} \mathrm{~m}$ ). W rzeczywistości rozdzielczości subpikometrowe sa nieosiagalne (atom helu ma w teorii 62 pikometry średnicy) nie ze względu na nature falowa wiazki, ale na niedoskonałość soczewek magnetycznych używanych w mikroskopii elektronowej. Dzięki mikroskopii elektronowej po raz pierwszy zwizualizowano cytoszkielet $i$ to głównie ona dostarcza informacji o ultrastrukturze tworzacych go komponentów (SviTKINA 2009).

Mikroskopia elektronowa wymaga specjalnie przygotowanego materiału. Jedna $z$ mniej skomplikowanych metod przygotowania próbki do EM, barwienie negatywne, polega na zatopieniu cienkiego plasterka utrwalonej chemicznie próbki w warstwie soli metalu ciężkiego (np. osmu i uranu), który pochłania wiązkę elektronów. Sole te słabo penetruja cząstki organiczne, przez co na obrazie elektronowym tworzone przez nie struktury sa znacznie jaśniejsze od tła (BoOTH i współaut. 2011). W ten sposób możliwe było zwizualizowanie filamentów aktynowych, mikrotubul i filamentów pośrednich in vitro, kontrastowanych octanem uranylu. Uzyskana rozdzielczość umożliwiła także zobrazowanie i zidentyfikowanie tych struktur w komórkach mięśniowych (IP i FISCHMAN 1979).

Niewątpliwym ograniczeniem tej techniki jest jednak brak informacji o strukturze przestrzennej badanych obiektów, ponieważ jednocześnie obrazowane sa dwuwymiarowe, cienkie skrawki próbki. $Z$ tego względu badacze cytoszkieletu wykorzystuja również inne podejście - metodę metalowej repliki obrazowanej w elektronowym mikroskopie skaningowym (ang. metal replica, metal shadowing), która pozwala zwizualizować topografię badanej struktury, dostarczajac danych o jej strukturze przestrzennej. Technika ta, poczatkowo stosowana głównie do obrazowania in vitro wirusów i wyizolowanych biomolekuł, polega na napyleniu na utrwaloną próbkę bardzo cienkiej (kilku nanometrowej) warstwy metalu ciężkiego i węgla. Metal ciężki, którym może być np. platyna czy iryd bądź ich mieszanka, umożliwia obrazowanie takiej „repliki” za pomoca wiąki elektronów, natomiast wegiel ma za zadanie ustabilizowanie powstałej struktury (WEPF i współaut. 1991, SviTKINA 2009). W ten sposób uzyskano m.in. dokładne informacje o strukturze i rozmiarach oligomerów tubuliny oraz filamentów pośrednich składających się $z$ desminy (SCHEELE i BORISY 1978, GEISLER i współaut. 1986). Pokazano także charakterystyczne rozgałęzianie się mikrofilamentów, możliwe dzięki jednemu $z$ białek wiążących aktynę, Arp 2/3, w keratynocytach Xenopus laevis (SVITKINA i BORISY 1999) i w warstwie kortykalnej Amoeba proteus (POMORSKI i współaut. 2007).

Opisane powyżej metody wizualizacji cytoszkieletu za pomoca mikroskopii elektronowej, jak każde zastosowanie tej techniki, niosa ze soba duże prawdopodobieństwo wprowadzenia artefaktów podczas wieloetapowej obróbki materiału biologicznego przed obrazowaniem. Dlatego też, do znacznego postępu w obrazowaniu struktur cytoszkieletarnych (i nie tylko) przyczyniła sie metoda cryo-EM, nad która prace, trwajace ponad dwie dekady, zostały w 2017 r. nagrodzone Nagrodac Nobla w dziedzinie chemii dla Jacques'a Dubocheta, Joachima Franka i Richarda Hendersona. W technice tej przygotowanie i obrazowanie prób zachodzi w bardzo niskich temperaturach (najczęściej w temperaturze ciekłego azotu, $-193^{\circ} \mathrm{C}$ ), w kawałku zeszkliwionego lodu. Taki lód nie tworzy kryształów, które mogłyby zniszczyć strukturę zamrażanego materiału. Dzięki użyciu wysokonapięciowych mikroskopów i zwiazanej $z$ tym niezwykle wysokiej rozdzielczości (poniżej 4 A, czyli 0,4 nm), która badacze sa $\mathrm{w}$ stanie obecnie uzyskać, technika ta jest stosowana jako alternatywa dla metod krystalograficznych. Brak suszenia, odwadniania i kontrastowania znaczacco ogranicza występowanie artefaktów, dzięki czemu cryo-EM jest metodą umożliwiajaca badanie biomolekuł, w tym cytoszkieletu, w formie najbardziej zbliżonej do fizjologicznej. Uzyskiwane obrazy charakteryzuja się jednak dużo mniejszym kontrastem niż w przy- 
padku technik wykorzystujacych znakowanie związkami metali ciężkich. Z tego względu, rozwój cryo-EM jest bardzo ściśle zwiąany ze stosowaniem coraz czulszych detektorów elektronów oraz opracowywaniem coraz doskonalszych metod obróbki obrazów (MURATA i Wolf 2018). Metoda ta pozwala nie tylko na badanie pojedynczych cząsteczek, ale też wielkich kompleksów białkowych, co stwarza ciekawe perspektywy w kontekście badań nad cytoszkieletem.

Turgay z współpracownikami wykorzystali EM do zbadania ultrastruktury filamentów pośrednich tworzacych blaszkę jądrowa - lamin (Turgay i Medalia 2017). Analiza przestrzennego ułożenia poszczególnych filamentów w sieciach laminowych wykazała, że sa one bardzo elastyczne. Ponadto, autorom udało się zaobserwować globularne struktury o średnicy $\sim 3,5 \mathrm{~nm}$, rozmieszczone na tetramerowych włóknach laminowych dokładnie co $20 \mathrm{~nm}$. Analiza profilu intensywności obrazu elektronowego pozwoliła zidentyfikować te struktury jako dimery laminowe. Stacd badacze zaproponowali nowy model filamentu, który zakłada naprzemienne występowanie odcinków tetramerowych i heksamerowych (tetramer $z$ bocznie dołaczonym dimerem) o precyzyjnie określonym wzorze.

Mikroskopia elektronowa umożliwia obserwację materiału wyłącznie po utrwaleniu, pozbawiajacc badacza szerszego biologicznego kontekstu, jaki zapewnia obserwacja przyżyciowa. $Z$ tego względu, często łączy się zalety EM oraz mikroskopii świetlnej stosujac mikroskopię korelacyjną (ang. correlative light and electron microscopy, CLEM). Tradycyjna mikroskopia korelacyjna wymaga zastosowania systemu precyzyjnych koordynatów przestrzennych, ponieważ próbka jest najpierw obrazowana za pomoca mikroskopu świetlnego, a następnie poddawana dodatkowej obróbce (odwadnianiu, kontrastowaniu i zatapianiu w żywicy), celem wizualizacji w mikroskopie elektronowym. Koordynaty umożliwiają nałożenie na siebie obu obrazów $z$ zachowaniem odpowiednich relacji przestrzennych. Metoda ta wiąże się jednak $z$ ryzykiem wprowadzenia artefaktów podczas przygotowania próbki do EM, a więc już po obrazowaniu w mikroskopie świetlnym (KUKULSKI i współaut. 2011). Problem ten pozwalaja obejść urządzenia łączace w sobie mikroskopię świetlna i EM (ang. integrated CLEM, iCLEM), w których skaningowy mikroskop konfokalny jest wbudowany w mikroskop elektronowy. Obrazowanie obiema metodami zachodzi tutaj sekwencyjnie, ale w jednym urządzeniu. Uzyskane obrazy sa od razu odpowiednio zorientowane względem siebie, a możliwość „podglądu” próbki w mikroskopie świetlnym znacznie ułatwia odna- lezienie w preparacie konkretnych komórek i struktur interesujacych badacza (AGRONSKAIA i współaut. 2008). Wyzwaniem jest w tym przypadku zastosowanie takiej metody przygotowania próbki, aby była ona jednocześnie widoczna w obu mikroskopach. Metale ciężkie, stosowane powszechnie do uzyskania kontrastu w mikroskopii elektronowej, moga powodować wygaszanie fluorescencji barwników i białek fluorescencyjnych znajdujacych się w ich pobliżu. Ponadto, samo odwodnienie próby również może negatywnie wpływać na świecenie niektórych $z$ nich. Opracowane protokoły zakładaja więc uzyskanie równowagi między zachowaniem fluorescencji a kontrastem widocznym w mikroskopie elektronowym. Zazwyczaj dąży się do sytuacji, w której kontrast jest na tyle wysoki, aby umożliwił uzyskanie odpowiedzi na pytanie badawcze, a nie by powstał doskonały obraz. Stąd też próby do zintegrowanej mikroskopii CLEM moga w ogóle nie być kontrastowane lub kontrastowane tylko w bardzo niewielkim stopniu (VOORTMAN i współaut. 2014).

Dzięki mikroskopii korelacyjnej udało się lepiej poznać mechanizm podziału komórki (GUIZETTI i współaut. 2011). Badacze początkowo obserwowali dzielace się komórki w mikroskopie fluorescencyjnym, aby następnie je utrwalić i zobrazować za pomoca mikroskopii elektronowej. Obrazowano w ten sposób kolejne stadia cytokinezy. Udało się stwierdzić, że w miejscu podziału cytoplazmy, oprócz mikrotubul, powstają również helikalne, kurczliwe filamenty zależne od kompleksu białkowego ESCRT-III (ang. endosomal sorting complexes required for transport), który odpowiada za transport pęcherzykowy. Wykazano, że to te filamenty sa niezbędne, aby ostatecznie przerwać ciagłość błony komórkowej i doprowadzić do rozdzielenia się komórek potomnych.

\section{METODY OBSERWACJI CYTOSZKIELETU W ŻYWYCH KOMÓRKACH}

Domeny fluorescencyjne a znakowanie białek cytoszkieletu

Niekwestionowana rewolucja w mikroskopii fluorescencyjnej miała miejsce w latach 90. XX w. wraz $z$ wykorzystaniem do wizualizacji fluorescencyjnego białka produkowanego bezpośrednio w badanym materiale. Znacznikiem tym było zielone białko fluorescencyjne (ang. green fluorescent protein, GFP). GFP odkryto w latach 60., w morskiej meduzie Aequorea victoria (SHIMOMURA i współaut. 1962), w latach 90. zsekwencjonowano jego gen, a kilka lat później wykorzystano go do stworzenia sztucznych konstruktów składajacych się $z$ badanego 
białka natywnego $z$ dodana domena fluorescencyjna (CHALFIE i współaut. 1994). Wprowadzenie takiego konstruktu do żywej komórki skutkuje produkowaniem przez nia zmodyfikowanych białek (tzw. białek fuzyjnych), które składaja się $\mathrm{z}$ zielonego białka fluorescencyjnego dołaczonego do praktycznie dowolnego innego białka interesujacego badaczy (Ryc. 2). Od tamtego czasu prace nad GFP zostały nagrodzone Nagroda Nobla w dziedzinie chemii w 2008 r., a same białka fluorescencyjne niezmiennie sa przedmiotem wielu badań $\mathrm{w}$ celu doskonalenia ich właściwości fluorescencyjnych, takich jak jasność i odporność na blaknięcie. Obecnie dostępny jest cały wachlarz białek, które emituja światło pokrywające praktycznie cały zakres światła widzialnego - od niebieskiego do podczerwieni. Powstały one na skutek wprowadzenia mutacji do oryginalnego zielonego białka fluorescencyjnego, bądź też zostały odkryte $\mathrm{w}$ innych organizmach żywych wykazujacych naturalna fluorescencję. Dzięki temu, podobnie jak w przypadku immunofluorescencji, przyżyciowa obserwacja materiału może odbywać się $z$ jednoczesnym użyciem kilku różnych znaczników, co jest nieocenione $\mathrm{w}$ badaniach biologicznych, także tych dotyczacych cytoszkieletu (CHUDAKOV i współaut. 2010).

Należy jednak mieć na uwadze, iż sama obecność znacznika fluorescencyjnego może nie być całkowicie obojętna dla funkcjonalności badanego białka. Może ona zaburzać lub uniemożliwiać jego oddziaływanie $z$ partnerami, lokalizację subkomórkowa, a także
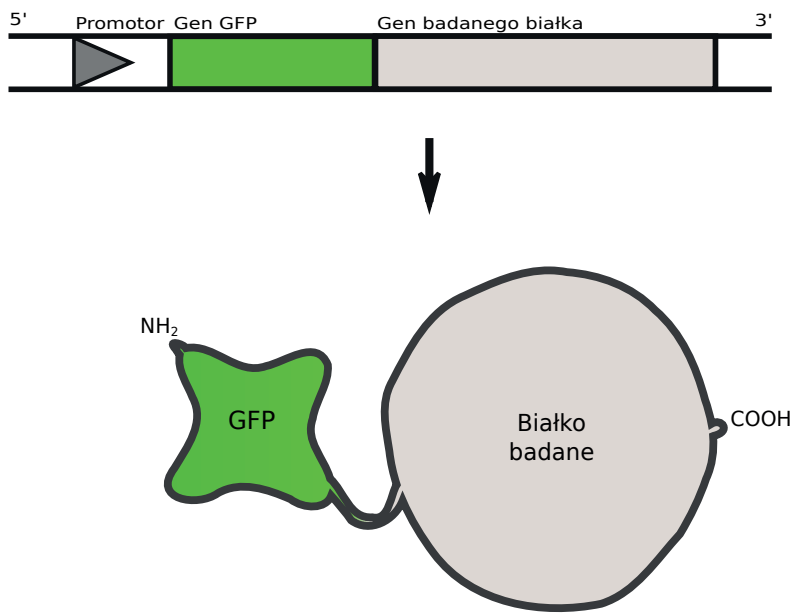

Ryc. 2. Schemat konstruktu zawierajacego GFP oraz białko fuzyjne.

Konstrukt składa się $\mathrm{z}$ genu GFP i genu badanego białka, umieszczonych jako jeden gen, pod kontrola tego samego promotora. W procesie translacji GFP i białko badane sa produkowane jako pojedyncza cząsteczka białka fuzyjnego. Na pokazanym przykładzie domena GFP znajduje się na aminowym końcu białka fuzyjnego. wpływać na dynamikę tworzenia polimerów. I tak np., dołaczenie eGFP (ang. enhanced green fluorescent protein) do końca aminowego cytoplazmatycznej $\beta$-aktyny zmieniało właściwości mechaniczne komórek, co wpływało na ich zdolność do migrowania. Okazało się, że synteza $\beta$-aktyny $z$ eGFP dołaczonym na końcu aminowym białka powodowała zmianę $\mathrm{w}$ stopniu spolimeryzowania aktyny endogennej (NAGASAKI i współaut. 2017). Opisywanych efektów nie zaobserwowano natomiast $\mathrm{w}$ przypadku fuzji na końcu karboksylowym. Badacze porównali również stosunek ilości G- do F-aktyny, rozdzielajac białka zawarte $\mathrm{w}$ badanych komórkach na frakcję rozpuszczalna (aktyna monomeryczna, G-aktyna) i odporna na działanie detergentu (aktyna filamentowa, F-aktyna), a następnie mierząc zawartość $\beta$-aktyny $w$ obu frakcjach za pomoca techniki immunodetekcji na błonie nitrocelulozowej (Western blot).

Sondy służące do przyżyciowego znakowania cytoszkieletu

Do wizualizacji filamentów tworzonych przez białka cytoszkieletu stosuje się również metody znakowania pośredniego. Polegaja one na syntezie białka fuzyjnego, składającego się ze znacznika fluorescencyjnego dołaczonego do białka inkrustujacego specyficznie struktury cytoszkieletu bądź fragmentu takiego białka. Takie podejście powoduje uzyskanie wyraźniejszych obrazów filamentów aktynowych lub mikrotubul, na skutek wyższego stosunku intensywności sygnału do tła niż w przypadku znakowania białkiem fluorescencyjnym monomerów tworzących filamenty (SLIOGERYTE i współaut. 2016). W tej sytuacji uzyskanie odpowiedniej jakości obrazów jest możliwe przy niższym poziomie ekspresji genów białka fuzyjnego, co jest korzystne ze względu na jego wpływ na procesy komórkowe. W przypadku F-aktyny, najczęściej stosowanymi markerami sa sprzężone $z$ białkiem fluorescencyjnym różne białka wiążace filamenty aktynowe: fimbryna, podjednostka ARP-3 kompleksu białkowego Arp2/3, tropomiozyna, F-traktyna (fragment złożony $z$ aminokwasów 10-52), utrofina człowieka (fragment złożony $\mathrm{z}$ aminokwasów 1-261) oraz opracowany stosunkowo niedawno Lifeact (złożony $z \quad 17$ reszt aminokwasowych fragment białka ABP-140 pochodzacego z Saccharomyces cerevisiae) (DELGADO-ÁlVAREZ i współaut. 2010, RIEDL 2010, MELAK i współaut. 2017). W przypadku mikrotubul, używane sa znakowane fluorescencyjnie białka EB1, wiążące końce „+" mikrotubul, oraz CLIP170/190, znakujące całe mikrotubule (FOLKER i współaut. 2005, MUROYAMA i LECHLER 2017; patrz JAWORSKI w tym zeszycie KOSMOSU). Opisywane podejście, po- 
dobnie jak bezpośrednie znakowanie białkami fluorescencyjnymi, może wpływać na strukturę i funkcję znakowanych elementów cytoszkieletu. Najczęściej obserwowane efekty syntezy takich znaczników to stymulacja tworzenia filamentów i stabilizowanie tych już istniejacych (MELAK i współaut. 2017). Ponadto, porównanie efektów znakowania F-aktyny za pomoca różnych znaczników fluorescencyjnych wykazało, że każde $z$ testowanych białek charakteryzowało się nieco inna lokalizacja w komórce względem falloidyny i preferencyjnie znakowało jedna lub kilka subpopulacji aktyny: w lamellipodium, filopodiach, włóknach naprężeniowych czy korteksie komórki (BELIN i współaut. 2014). $\mathrm{W}$ efekcie, przeprowadzając doświadczenia z wykorzystaniem opisywanych znaczników, nie tylko warto minimalizować ekspresję ich genów, ale także rozważyć wykorzystanie więcej niż jednego markera, aby zwiększyć wiarygodność uzyskiwanych wyników.

\section{METODY FUNKCJONALNE}

\section{FLUORESCENCYJNA MIKROSKOPIA PUNKTOWA I RUCH MONOMERÓW W POLIMERACH CYTOSZKIELETALNYCH}

Zarówno mikrotubule, jak i mikrofilamenty aktynowe sa polimerami spolaryzowanymi. Mikrofilamenty maja łatwo rozróżnialne końce: plus lub kolczasty (ang. barbed end) $i$ minus lub ostry (ang. pointed end). Końce mikrotubul również oznacza się jako plus i minus. Na końcu plus eksponowana jest podjednostka $\beta$-tubuliny dimeru, natomiast na końcu minus, a-tubuliny. W obu przypadkach polaryzacja ta jest istotna przy wzroście długości włókien i dodawanie nowych monomerów odbywa się na końcu + polimerów (patrz RĘDOWICZ oraz NIEZNAŃSKA w tym zeszycie KOSMOSU). Istnieje jednak inny aspekt tego zjawiska, który badać możemy tylko metodami mikroskopowymi. Z polaryzacją filamentów aktynowych i mikrotubul wiąże się zjawisko, polegające na przesuwaniem się monomerów wewnątrz struktury polimeru od końca plus (gdzie sa przyłączane do polimeru) do końca minus (gdzie sa odłączane). Zjawisko to zwane jest $z$ angielska „treadmillingiem”. Taki ruch wewnatrz struktury można obserwować, jeśli do struktury polimeru wprowadzimy losowo pojedyncze, fluorescencyjne monomery. Tak powstała FSM (ang. fluorescent speckle microscopy), czyli fluorescencyjna mikroskopia punktowa. To, że taka technika jest praktycznie możliwa, pokazali Clair Waterman-Storer i Ted Salmon, najpierw na mikrotubulach (WATERMAN-STORER i SALMON 1998), a potem na mikrofilamentach (WATERMAN-STO-
RER i współaut. 1998). Technika oryginalnie polegała na wstrzyknięciu małej ilości znakowanego fluorescencyjnie białka do badanej komórki. Ilość sondy była tak dobrana, by nie przekraczała ona $5 \%$ natywnej puli białka w komórce. Dzięki temu udało się uniknać problemów $z$ nadmiarem fluorescencji tła. Jednocześnie, podczas polimeryzacji fluorescencyjnie znakowane białko współzawodniczyło $z$ natywnym, tworzac charakterystyczny wzór świecacych kropek, który następnie można było śledzić i obserwować ruch pojedynczych monomerów w polimerze. Wykorzystujacc tę metodę badacze pokazali, że w komórkach kultur pierwotnych $z$ płuc traszki (Taricha granulosa) mikrotubule przejawiają zarówno dynamiczna niestabilność, jak i klasyczny „treadmilling”. Co więcej, sama dekompozycja cytoszkieletu aktynowego powodowała zanik dynamicznej niestabilności mikrotubul, a nie wpływała na ruch podjednostek od końca plus mikrotubul ku środkowi komórki (WATERMAN-STORER i SALMON 1997). Wraz $z$ upływem czasu technika ta stała się w pełni ilościowa (DANUSER i WATERMAN-STORER 2006) i do dziś jest używana w analizie dynamiki cytoszkieletu w żywych komórkach (ATHAMNEH i współaut. 2017).

\section{NAPRĘŻENIA W CYTOSZKIELECIE}

\section{Elastyczne podłoża i nieinwazyjne pomiary naprężeń cytoszkieletu}

Jedna z funkcji cytoszkieletu jest wytwarzanie siły mechanicznej kosztem hydrolizy cząstek ATP. Ta funkcja, najbardziej znana z komórek mięśniowych, oparta jest przede wszystkim na interakcjach filamentów aktynowych $z$ filamentami miozyny (zwłaszcza tymi $z$ rodziny II, a dokładniej $z$ domenami motorycznymi ciężkich łańcuchów miozyny). Więcej informacji o miozynach w artykułach SuszeK i współaut. oraz NowAK i REDOWICZ w tym zeszycie KOSMOSU. Opisane poprzednio metody pozwalaja na obrazowanie składu białek aparatu kurczliwego, obecnego w innej wprawdzie postaci, nie tylko w mięśniach. Powstały również metody pozwalające na mikroskopowe badanie sił powstajacych podczas skurczu aktomiozyny w żywej komórce. Metody te polegaja na zastosowaniu elastycznego podłoża, które pod wpływem działania sił ulega odkształceniu. Poczatkowo była to metoda jakościowa, polegajacca na obserwacji wielkości zmarszczek powstajacych na cienkim, elastycznym podłożu, zawieszonym na płynnym podkładzie (HARRIs i współaut. 1980). W celu uzyskania wyników ilościowych zmieniono podejście i w podłożu zatopiono drobne koraliki, które po wysianiu komórek zmieniaja położenie 
w miarę odkształcania się podłoża wskutek działania siły generowanej przez cytoszkielet. Na podstawie tych przesunięć możliwe jest obliczenie naprężeń przenoszonych na podłoże (DEMBo i współaut. 1996). Wraz ze wzrostem mocy obliczeniowych komputerów i doskonaleniem podłoży, metodyka stała się łatwiejsza w stosowaniu, a wynikiem jej zastosowania sa dokładne mapy naprężen wytwarzanych przez komórkę (HIND i współaut. 2015). Metodyka ta doczekała się ciekawej modyfikacji, w której zastosowano trójwymiarowe obrazowanie bloku elastycznego podłoża $z$ zatopionymi znacznikami. Dzięki temu możliwy jest pomiar nie tylko sił w płaszczyźnie równoległej do podłoża, ale także prostopadłych. Ta metoda pozwala obrazować cały złożony wzór mechanicznych oddziaływań między komórka a jej otoczeniem (FRANCK i współaut. 2011). Chociaż metody rejestracji sił można uznać za powtarzalne i wystarczajaco dokładne, to sa one skomplikowane technicznie i złożone obliczeniowo, trudno zatem wyobrazić sobie ich powszechne użycie.

Znacznie prostsza metoda analizy przylegania komórek do podłoża jest mikroskopia IRM (ang. interference reflection microscopy). Nie pozwala ona co prawda na określenie faktycznej siły, ale umożliwia pomiar odległości błony komórkowej od szkiełka nakrywkowego, na którym znajduje się komórka. Pomiar ten odbywa się za pomoca interferencji światła odbitego od błony komórkowej i szkła podłoża (CURTIS 1964, VERSCHUEREN 1985). Metoda, mimo iż mniej doskonała niż bezpośredni pomiar naprężeń, jest jednak prosta i doskonale łaczy się $z$ innymi metodami fluorescencyjnymi takimi, jak zastosowanie sond molekularnych do pomiaru aktywności białek czy stężenia jonów w cytoplazmie i badania zależności między badanymi tymi metodami zjawiskami a ruchem i adhezja komórki (POMORSKI i współaut. 2004).

Inwazyjna metoda badania naprężeń cytoszkieletu

Inwazyjna metoda badania naprężeń cytoszkieletu jest metoda polegajacca na niszczeniu cząsteczek białka, $z$ którym związano barwnik (ang. chromofore assisted laser inactivation, CALI). Jak wiadomo, każdy barwnik pochłania światło o określonej długości i ulega pod jego wpływem wzbudzeniu. Jeśli ilość światła będzie zbyt duża, może dojść do termicznego zniszczenia cząstki zwiazanej z barwnikiem. Początkowo, metoda ta oparta była o zieleń malachitowa, barwnik toksyczny dla komórek (JAY 1988). Przy odpowiedniej konfiguracji systemu doświadczalnego wykazano, że można do dezaktywacji białka wykorzystać zwiąaną $z$ nim domenę eGFP (RAJFUR i współaut. 2002). Udowodniono, że wiązka laserowa można zniszczyć zwiąana z eGFP a-aktyninę, białko wchodzace w skład włókien naprężeniowych, i w ten sposób zerwać integralność pojedynczego włókna. Precyzja takiego cięcia jest ograniczona jedynie obszarem, do jakiego można zogniskować wiąkę światła przez obiektyw (około ćwierć um średnicy).

\section{BADANIA MECHANIZMÓW REGULACJI FUNKCJI CYTOSZKIELETU}

Sondy molekularne

Techniki mikroskopowe umożliwiaja nie tylko przyżyciowe badanie cytoszkieletu na poziomie struktury, ale również funkcji. Znakowanie fluorescencyjne (chemiczne lub biologiczne) nie ogranicza się tylko do emisji światła o określonej długości fali przy odpowiednim wzbudzeniu. W latach 40. ubiegłego wieku odkryto bowiem zjawisko przenoszenia energii między barwnikami fluorescencyjnymi na drodze innej niż promieniowanie, które nazwano nazwiskiem badacza, który po raz pierwszy je opisał - Förster resonance energy transfer (FRET).

Zjawisko to $\mathrm{w}$ uproszczeniu polega na przekazaniu energii przez jedna wzbudzoną cząsteczkę fluorescencyjną (zwaną donorem) innej czasteczce fluorescencyjnej (zwanej akceptorem). W efekcie, populacja pierwszej z cząsteczek świeci słabiej, a drugiej mocniej niż miałoby to miejsce, gdyby zjawisko FRET nie zachodziło (HOCHREITER i współaut. 2015). Najprościej rzecz ujmując, za pomoca mikroskopu porównuje się stosunek intensywności fluorescencji obu fluorochromów. Aby przekazanie energii miało miejsce, musi być jednak bardzo precyzyjnie spełniony podstawowy warunek, a mianowicie cząsteczki, między którymi dochodzi do transferu energii, musza znajdować się w bardzo niewielkiej odległości, wynoszacej około 3-6 nm. Przy czym efektywność transferu spada $z$ szósta potęga odległości między cząsteczkami. Ponadto, akceptor i donor musza mieć zbliżone widma wzbudzenia i emisji, tzn. widmo emisji donora musi pokrywać się częściowo $z$ widmem wzbudzenia akceptora. Stąd też opracowano wiele chemicznych i biologicznych par FRET, czyli par czasteczek fluorescencyjnych o widmach odpowiednio dobranych, aby zjawisko FRET między nimi zachodziło wydajnie. Przykładem takiej pary sa niebiesko-zielone (ang. cyan fluorescent protein, CFP) i żółte (ang. yellow fluorescent protein, YFP) białka fluorescencyjne. Szczególnym przypadkiem zastosowania zjawiska FRET jest połaczenie pary białek fluorescencyjnych w jedna cza- 

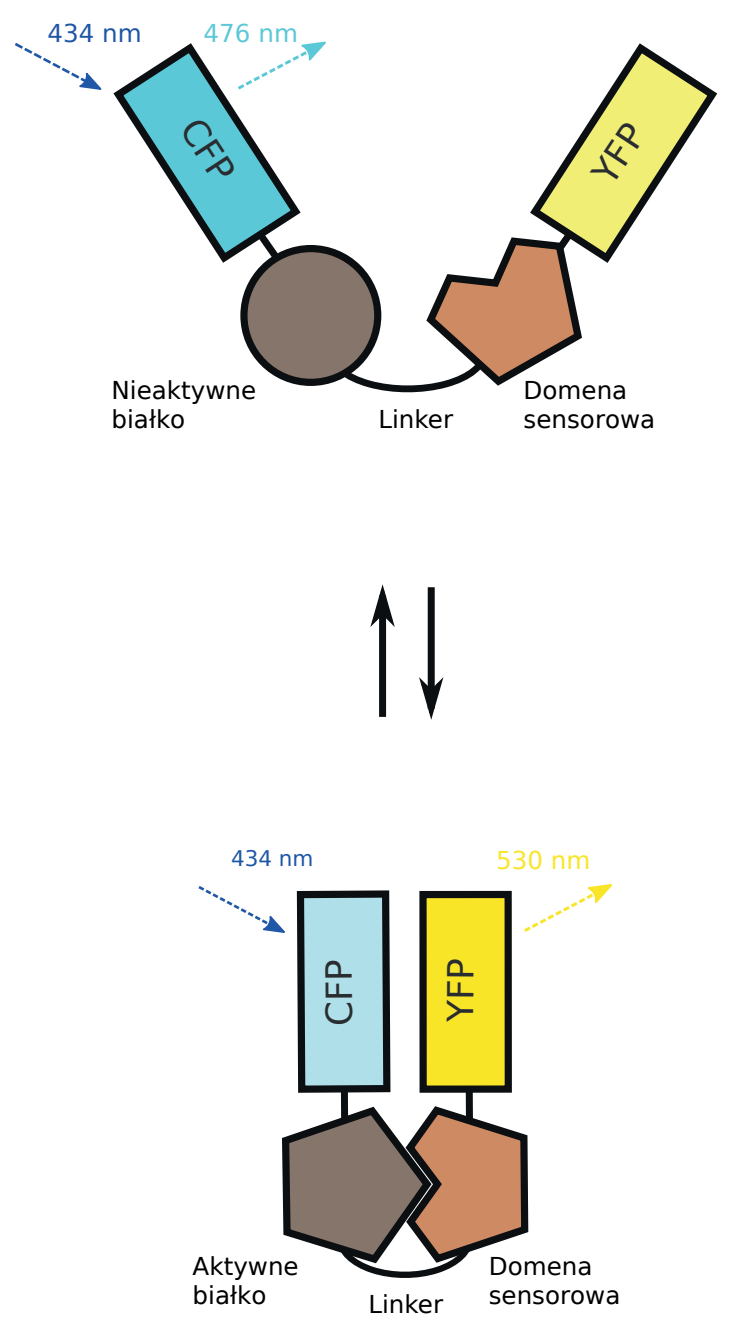

Ryc. 3. Schemat działania sensora FRET.

Sensor zawiera badane białko połaczone elastycznym łącznikiem $z$ białkową domeną sensorową wiążąca badane białko w formie aktywnej. Oba białka sa wyznakowane domenami fluorescencyjnymi tworzacymi parę FRET, w tym przypadku CFP i YFP. Kiedy białko badane jest w formie nieaktywnej, nie jest wiązane przez domenę sensorową, a domeny fluorescencyjne znajdują się w tak dużej odległości od siebie, że zjawisko FRET nie zachodzi, a wzbudzenie donora (CFP) skutkuje emisja fluorescencji niebiesko-zielonej. Zaktywowanie badanego białka powoduje związanie go przez domenę sensorowa i zbliżenie do siebie fluoroforów na taka odległość, że zjawisko FRET zachodzi w sposób wydajny. Wzbudzenie donora powoduje teraz przekazanie energii akceptorowi i emisję żółtej fluorescencji przez domenę YFP.

steczkę, w której zjawisko FRET zachodzi lub nie w zależności od przyjętej przez białko fuzyjne konformacji. Jednym $z$ najciekawszych zastosowań takich konstruktów jest opracowywanie kodowanych biologicznie sond, które umożliwiają m.in. wizualizację stopnia aktywności białek, w tym tych odpowiedzialnych za regulację cytoszkieletu. Mamy wówczas do czynienia $z$ białkiem fuzyjnym składajacym się $z$ donora, badane-

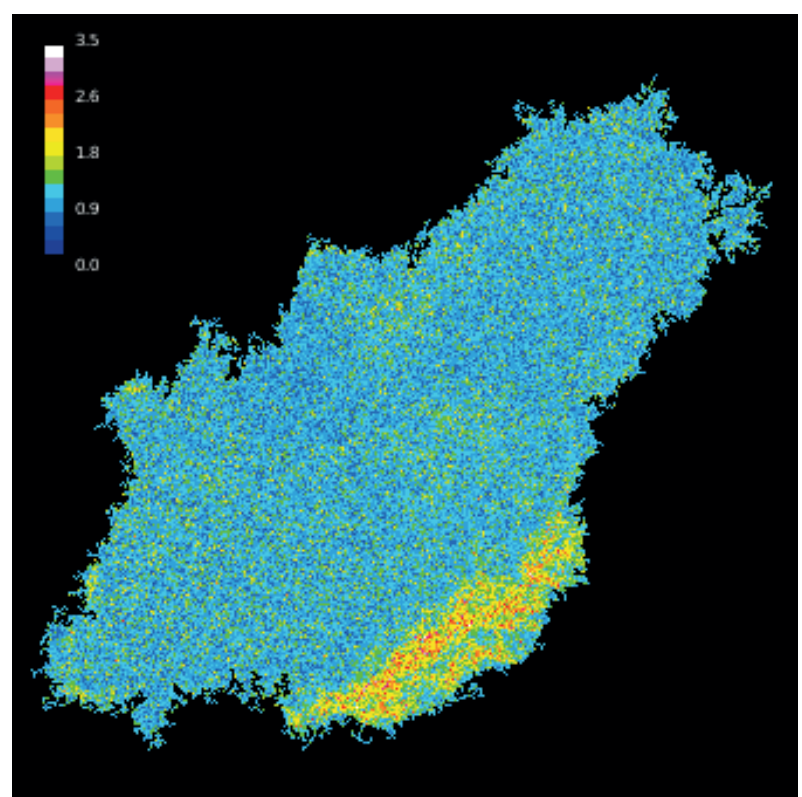

Ryc. 4. Przykładowy obraz otrzymany przy użyciu sondy FRET.

Komórki U-251 MG produkujące sensor aktywności białka Rac1 - Raichu-Rac1 (ITOH I współaut. 2002), z widoczna zwiększona aktywacją białka w obszarze lamellipodium. Skala barw przedstawia stosunek intensywności obrazu akceptora do obrazu donora. Dla zwiększenia czytelności obrazu obszar poza komórka został zamaskowany. Obraz został uzyskany przez Autorów przy pomocy odwróconego mikroskopu fluorescencyjnego Axio Observer Z.1 (Zeiss) z modułem konfokalnym Spinning Disc CSU-X1 (Yokogawa Electric Corporation) i komora przyżyciowa. Preparat obserwowano za pomoca obiektywu HC Apo 63x/1.20 (Zeiss) z imersja wodna. Do wzbudzenia zastosowano laser diodowy 405 $\mathrm{nm}$. Emisję fluorescencji rejestrowano jednocześnie za pomoca dwóch kamer Evolve 512 (Photometrics) w zakresie 419-465 nm (donor) i 500-550 nm (akceptor).

go białka, domeny wiążącej badane białko w stanie aktywnym (część sensorowa) oraz akceptora. Aktywacja badanego białka w komórce powoduje zwiąanie go przez domenę sensorowa i zbliżenie do siebie pary FRET (Ryc. 3). W efekcie, na obrazie mikroskopowym widoczne jest znaczne zwiększenie wydajności zjawiska FRET (SEKAR i PERIASAMY 2003).

W przypadku cytoszkieletu często używanymi sondami molekularnymi sa biosensory aktywności białek $z$ rodziny małych GTPaz: Rho, Rac i Cdc42, będących kluczowymi regulatorami cytoszkieletu aktynowego (Ryc. 4). Narzędzia te umożliwiły poznanie czasowo-przestrzennych wzorów aktywacji tych białek w komórce podczas jej przemieszczania się, fagocytozy, formowania podosomów czy pod wpływem sił ścinajacych (HANNA i współaut. 2014, MARTIN i współaut. 2016, SHAO i współaut. 2017). 
Mikroskopia TIRF jako metoda badania obecności białek regulatorowych w błonie komórkowej

Wśród licznych metod stosowanych w mikroskopii optycznej, część ma charakter „trików technicznych" pozwalajacych w prosty sposób rozwiazywać trudne problemy. Do takich szczególnych technik należy wykorzystanie mikroskopii całkowitego wewnętrznego odbicia (ang. total internal reflection fluorescent microscopy, TIRF) do obrazowania ruchu czastek fluorescencyjnych pomiędzy cytoplazma a wentralna (brzuszna, czyli ta która bezpośrednio styka się ze szkiełkiem nakrywkowym) błona cytoplazmatyczna komórki. Mikroskopia TIRF wykorzystuje efekt polegajacy na wystepowaniu fali ewanescencyjnej, emitowanej przez powierzchnię, od której odbija się światło. Fala ta pozwala wzbudzić cząstki barwnika znajdujace się w pobliżu granicy ośrodków, nawet jeśli światło ulega całkowitemu odbiciu na tej granicy $i$, zgodnie $z$ optyka klasyczna, nigdy do cząstek barwnika nie dociera. Fala elektromagnetyczna nie może być lokalnie nieciagła, co powoduje powstanie przy granicy ośrodków pola zdolnego do wzbudzania barwnika. Głębokość tego pola jest zwiazana $z$ częstotliwościa fali elektromagnetycznej światła i katem jego padania na powierzchnie, i w typowych przypadkach wynosi około $100 \mathrm{~nm}$. Pozwala to na wybiórcze obserwowanie zjawisk zachodzacych w przylegajacej do szkiełka nakrywkowego błonie, $z$ pominięciem zjawisk zachodzacych w głębi cytoplazmy (AXELROD 1981).

Jednym $z$ zastosowań tej metody obserwacyjnej, jest badanie składu lipidowego błony przy pomocy fluorescencyjnie znakowanych białek zdolnych do wiazania określonych jej komponentów. Wiele $z$ tych komponentów ma działanie regulatorowe i uczestniczy w przekazywaniu sygnałów $z$ otoczenia komórki do jej wnętrza. Z punktu widzenia regulacji struktury cytoszkieletu, jak i będącej jej rezultatem, kontroli ruchu komórki, ważna jest obserwacja dynamiki powstawania 3,4,5-trisfosforanu fosfatydyloinozytolu $\left(\mathrm{PIP}_{3}\right)_{\text {Z }}$ 4 4,5-bisfosforanu fosfatydyloinozytolu. Ta reakcja, katalizowana przez enzym kinazę PI3, jest pozytywnym sygnałem sterujaccym kierunkowościa ruchu komórki. $\mathrm{PIP}_{3}$ wiąże się specyficznie $z$ domena białkowa zwana domena homologii plekstryny (ang. plextrin homology domain, PH). Białko fluorescencyjne wyposażone w taką domenę będzie się gromadziło w pobliżu obszarów błony, w których jest podwyższone stężenie $\mathrm{PIP}_{3}$. Wykorzystanie mikroskopii TIRF pozwala wybiórczo obserwować błonę adherujacej komórki i obrazować zmiany stężenia białka $z$ domena PH w jej pobliżu. Dzięki temu można w żywej komórce obserwować sygnały sterujące kierunkiem jej ruchu (WEIGER i współaut. 2009). Autorzy pracy stosuja w swoich badaniach dość nietypową konfiguracje mikroskopu TIRF. Większość dostępnych na rynku konfiguracji tej mikroskopii opiera się na wprowadzeniu światła wzbudzającego przez obiektyw o bardzo dużej aperturze numerycznej (ang. numerical aperturę, NA). Apertura numeryczna jest miara rozwartości stożka, $z$ którego obiektyw jest w stanie zbierać światło. Duża apertura charakteryzuje obiektywy bardzo jasne, apertury powyżej wartości 1 wymagaja użycia olejku immersyjnego i maja duże powiększenia, zazwyczaj powyżej 60x. Tak duże powiększenia nie sprzyjaja badaniu ruchu komórek, wypełniajacych zbyt dużą część pola widzenia, by zarejestrować na jednym obrazie długa trajektorię ruchu. $Z$ tego powodu autorzy pracy stosuja obiektyw o niewielkim powiększeniu, a światło wzbudzające wprowadzają bezpośrednio do specjalnego pryzmatu, przyklejonego do szkiełka nakrywkowego. Takie systemy nie sa komercyjnie dostępne, co poważnie ogranicza możliwość stosowania metody.

Mikroskopia TIRF jest też używana w metodach in vitro, podczas obserwacji poruszania znakowanych fluorescencyjnie włókien cytoszkieletu (zarówno mikrotubul, jak i mikrofilamentów) przez immobilizowane białka motoryczne. Mała głębia wzbudzenia fluorescencji mikroskopu TIRF powoduje, że obserwacje nie sa zakłócane przez fluorescencję włókien nie związanych białkami motorycznymi (SzCZESNA i KASPRZAK 2016).

\section{MIKROSKOPIA SUPERROZDZIELCZA W BADANIU STRUKTUR CYTOSZKIELETU}

Nie miejsce tu na techniczny opis zagadnienia zdolności rozdzielczej mikroskopu optycznego, niemniej jednak czytelnik powinien zdawać sobie sprawę, że przestrzenna bariera obrazowania przy pomocy takiego mikroskopu istnieje i zależy ona od długości fali świetlnej używanej do tworzenia obrazu przez obiektyw. Rozdzielczość ta wynosi około ćwierć mikrometra dla współczesnych mikroskopów wyposażonych w najwyższej jakości obiektywy immersyjne i jest o rząd wielkości za niska, by precyzyjnie obrazować większość struktur białkowych. Na przełomie wieków opracowano jednak szereg technik, pozwalajacych przełamać ograniczenie zdolności rozdzielczej i określanych wspólnym mianem „mikroskopii superrozdzielczej". Ten sukces przyniósł autorom Nagrodę Nobla w 2014 r. i został opisany w artykule poświęconym tej nagrodzie w numerze Kosmosu z 2015 r.; wszystkich zainteresowanych podstawami mikroskopii superrozdzielczej odsyłam 
do tego artykułu (POMORSKI 2015). Biorac pod uwage średnicę mikrofilamentów ( 8-9 $\mathrm{nm})$ czy mikrotubul ( 24 $\mathrm{nm} \mathrm{z}$ kanałem w środku o średnicy $\sim 12 \mathrm{~nm})$, zdolność rozdzielcza mikroskopu świetlnego jest absolutnie niewystarczajaca do tego, by rozróżniać pojedyncze filamenty. Nawet złożone struktury, jakimi sa kontakty zogniskowane, nie przekraczaja $200 \mathrm{~nm}$ średnicy i ich struktura pozostaje poza zasięgiem zwykłego, nawet bardzo dobrego, mikroskopu optycznego i w związu $z$ tym mikroskopia superrozdzielcza wydaje się być narzędziem stworzonym do badań skomplikowanych struktur cytoszkieletalnych.

Techniki mikroskopii superrozdzielczej pozwalaja rozróżniać obiekty tak małe jak 20 nm i wydawałoby się, że jako takie stanowia idealne narzędzie do wizualizacji struktur cytoszkieletu. Niestety, w beczce miodu jaka stanowia techniki superrozdzielcze, jest łyżka dziegciu: doskonała rozdzielczość jest łatwa do uzyskania na płaszczyźnie, w osiach $\mathrm{x}$ i y obrazu, ale nie $\mathrm{w}$ trzecim wymiarze. Uzyskanie porównywalnie dokładnego pomiaru położenia białka w pionie, w płaszczyźnie prostopadłej do płaszczyzny obrazu, stanowi poważny problem.

Złożone struktury zwiazane $z$ funkcjonowaniem cytoszkieletu sa trójwymiarowe i ich obrazowanie wymaga wysokiej rozdzielczości we wszystkich trzech wymiarach. Doskonałym przykładem takiego kompleksu białkowego, którego trójwymiarowa struktura została zobrazowana przy pomocy technik superrozdzielczych, sa kontakty zogniskowane (ang. focal contacts). Kotwicza one zbudowane głównie $z$ aktyny i miozyny II włókna naprężeniowe w błonie komórkowej. Aby stworzyć mikroskopowy model struktury kontaktu zogniskowanego, grupa Clare M. Waterman $z$ National Institutes of Health w Bethesdzie musiała wizualizować wzajemne pozycje aż dziewięciu białek uczestniczacych $\mathrm{w}$ budowie tej struktury: integryny $\mathrm{a}_{\mathrm{v}}$, paksyliny, taliny, winkuliny, zyksyny, a-aktyniny, aktyny oraz kinazy FAK (ang. focal adhesion kinase) i białka VASP (ang. vasodilator-stimulated phosphoprotein) (KANCHANAWONG i współaut. 2010). Do obrazowania zastosowano technikę PALM, która wymaga stosowania fotoaktywowalnych znaczników. W tym przypadku wybrano fotoaktywowalne białko fluorescencyjne mEos, będące wariantem białka pochodzacego $z$ koralowca Lobophyllia hemprichii (MCKInNeY i współaut. 2009). Białko to pod wpływem naświetlania światłem $Z$ bliskiego UV (A $390 \mathrm{~nm}$ ) zmienia własności fluorescencyjne. Przed naświetleniem białko emituje światło zielone (A $516 \mathrm{~nm}$ ) w odpowiedzi na wzbudzenie światłem niebieskim
( $1506 \mathrm{~nm}$ ), a po naświetleniu emisja zmienia się na czerwona ( $\lambda 581 \mathrm{~nm}$ ), wymagająca wzbudzania światłem żółto-zielonym ( $\lambda$ $571 \mathrm{~nm})$. Wymóg zastosowania białka fotoaktywowalnego wynika $z$ natury metody PALM i silnie ogranicza wybór znacznika, powodując konieczność osobnej wizualizacji każdego $z$ badanych białek. Do wyznaczenia pozycji białek konieczne jest określenie ich odległości od błony plazmatycznej, co wymaga precyzyjnego określenia położenia w osi Z. Do tego celu użyta została wersja mikroskopu PALM, iPALM, wykorzystujacca interferencje światła i pozwalajaca określać średnie położenia białek w osi Z (SHTENGEL i współaut. 2009). Niektóre $z$ obrazowanych białek mają wyraźnie wydłużona strukturę i dla ustalenia ich względnych pozycji konieczne okazało się obrazowanie dwóch białek fuzyjnych: osobno zawierajacych znacznik fluorescencyjnych na końcu aminowym i osobno na końcu karboksylowym białka. Tak postapiono $z$ paksylina, talina $\mathrm{i}$ a-aktynina. Okazało się, że tylko talina wykazywała rzeczywista rozciagłość przestrzenna w osi $Z$ i koniec karboksylowy białka był średnio oddalony o $40 \mathrm{~nm}$ od jego końca aminowego. Problemem okazała się wzrastajaca wraz $z$ oddalaniem się od powierzchni preparatu niepewność określenia położenia w osi z. Dla białek położonych w pobliżu błony plazmatycznej wynosiła ona około 5 $\mathrm{nm}$, a w odległości $100 \mathrm{~nm}$ od błony osiągała już $30 \mathrm{~nm}$. Autorzy wykazali podział struktury kontaktu na szereg warstw funkcjonalnych: przekazująca sygnały warstwę integrynowa (integryny, paksylina, kinaza FAK), warstwę przekazujaca siły mechaniczne (talina, winkulina), warstwę regulujacca strukturę aktyny (VASP, zyksyna, aktyna) oraz początek włókien naprężeniowych (aktyna, a-aktynina). Dopiero jednak obrazowanie szeregu skróconych analogów taliny (LIU i współaut. 2015) pozwoliło wykazać, że właśnie to białko jest kluczowym elementem łaczącym integryny $z$ włóknami naprężeniowymi. Białko to rozciaga się na długości około $100 \mathrm{~nm}$ i jest nachylone pod katem $15^{\circ}$ do powierzchni błony. Dokładna lektura powyżej cytowanych prac $z$ jednej strony ujawnia wielki potencjał mikroskopii superrozdzielczej w badaniach struktur cytoszkieletu, z drugiej, pokazuje jak trudne i skomplikowane sa takie badania pod względem technicznym. Autorzy wiedza o istnieniu jedynie dwóch mikroskopów iPALM na świecie, jeden znajduje się w Janelia Research Campus Instytutu Medycznego Howarda Hughes'a w Ashburn w USA, a drugi w Instytucie Mechanobiologii na Narodowym Uniwersytecie Singapuru. 


\section{PODSUMOWANIE}

Struktura cytoszkieletu komórek eukariotycznych i dynamika czasowa jego zmian stwarzaja optymalne warunki do zastosowania metod mikroskopii optycznej w ich badaniu. Długie i cienkie filamenty, występujace $\mathrm{w}$ komórkach niemięśniowych $\mathrm{w}$ postaci relatywnie rzadkiej sieci, daja się łatwo obserwować. Jednocześnie, stabilność struktur cytoszkieletu pozwala na stosunkowo łatwe utrwalanie i barwienie. Dzięki tym cechom, badania mikroskopowe nie tylko stały się nieodzownym elementem badań nad cytoszkieletem, ale jednocześnie były poligonem skutecznie weryfikujacym zastosowanie tych technik do znakowania i lokalizacji innych białek i struktur, znacznie mniej stabilnych i mniejszych niż cytoszkielet. Włókna cytoszkieletu maja tak charakterystyczna strukturę, że można je łatwo identyfikować również $\mathrm{w}$ obrazach pochodzacych $\mathrm{z}$ mikroskopu elektronowego i nie wymaga to żadnego dodatkowego znakowania. Mikroskopia elektronowa, ze swoja subnanometrowa rozdzielczością, pozwoliła weryfikować rezultaty pochodzace $z$ badań prowadzonych przy użyciu metod mikroskopii optycznej i nabrać zaufania do obrazów uzyskiwanych $\mathrm{z}$ rozdzielczościa znacznie mniejsza niż rozmiary badanych białek czy struktur. To badania cytoszkieletu pokazały, że wykorzystujac mikroskopię optyczną można w ogóle obrazować struktury, których wymiary sa znacznie mniejsze niż zdolność rozdzielcza mikroskopu optycznego i włókna o średnicy wielokrotnie od niej mniejszej tworzą wyraźne obrazy. Można więc zaryzykować stwierdzenie, że to badania nad cytoszkieletem przetarły droge dla wszystkich współczesnych badań struktur biologicznych, jakie prowadzimy dziś z użyciem mikroskopii optycznej.

$$
\text { Streszczenie }
$$

Cytoszkielet to sieć białkowych polimerów oraz zwiazanych $\mathrm{z}$ nimi setek białek motorycznych, regulatorowych i łączacych cytoszkielet $z$ innymi strukturami komórkowymi. Rozwój wiedzy o cytoszkielecie jest nierozerwalnie zwiększany $z$ postępem technik mikroskopowych używanych do jego obserwacji. Początki tych badań to niespecyficzne, nieskomplikowane barwienia utrwalonego materiału biologicznego, które później rozwinęly się w nowoczesną mikroskopię strukturalna, pozwalająca na precyzyjne znakowanie określonych białek tworzacych cytoszkielet, badanie ich stanu fizjologicznego czy też oddziaływań cytoszkieletu $z$ luźno związanymi białkami błony czy cytoplazmy. Obecnie możliwe jest nie tylko obrazowanie struktury i funkcji cytoszkieletu ze znacznie lepsza rozdzielczością przestrzenna, ale także prowadzenie tych obserwacji na żywym materiale biologicznym. Z drugiej strony, stabilność cytoszkieletu umożliwia poszukiwanie nowych metod jego obrazowania, co niewątpliwie należy do kół napędowych postępu, jaki dokonał się i wciaż dokonuje się w dziedzinie mikroskopii.

\section{LITERATURA}

Agronskaia A. V., VAlentiJn J. A., VAN DRIEL L. F., Schneiddenberg C. T. W. M., Humbel B. M., VAN BERGEN EN HENEGOUWEN P. M. P., VERKleiJ A. J., Koster A. J., GerRitsen H. C., 2008. Integrated fluorescence and transmission electron microscopy. J. Struct. Biol. 164, 183-189.

ANDERSEN R. A., BARR D. J. S., LYNN D. H., MELKONIAN M., MOESTRUP O., Sleigh M. A., 1991. Terminology and nomenclature of the cytoskeletal elements associated with the flagellar/ ciliary apparatus in protists. Protoplasma 164, $1-8$.

ANDERSON M. O., SHElat A. A., GuY R. K., 2005. A solid-phase approach to the phallotoxins: total synthesis of [Ala7]-phalloidin. J. Org. Chem. 70, 4578-4584.

ASKONAS B. A., Williamson A. R., WRIGHT B. E., 1970. Selection of a single antibody-forming cell clone and its propagation in syngeneic mice. Proc. Natl. Acad. Sci. USA 67, 13981403.

Athamneh A. I. M., He Y., LamoureuX P., FIX L., Suter D. M., Miller K. E., 2017. Neurite elongation is highly correlated with bulk forward translocation of microtubules. Sci. Rep. 7, 7292 .

AXELROD D., 1981. Cell-substrate contacts illuminated by total internal reflection fluorescence. J. Cell Biol. 89, 141-145.

Belin B. J., Goins L. M., Mullins R. D., 2014 Comparative analysis of tools for live cell imaging of actin network architecture. Bioarchitecture 4, 189-202.

Booth D. S., AVILA-Sakar A., Cheng Y., 2011. Visualizing proteins and macromolecular complexes by negative stain EM: from grid preparation to image acquisition. J. Vis. Exp., doi: $10.3791 / 3227$

BURNET F. M., 1976. A modification of Jerne's theory of antibody production using the concept of clonal selection. CA. Cancer J. Clin. 26, 119-121.

Chalfie M., Tu Y., Euskirchen G., WARD W. W., PRASHER D. C., 1994. Green fluorescent protein as a marker for gene expression. Science 263, 802-805.

Chudakov D. M., MATZ M. V, LukYanov S., LuKYANOV K. A., 2010. Fluorescent proteins and their applications in imaging living cells and tissues. Physiol. Rev. 90, 1103-1163.

CoOns AlBert H., Hugh J., CREECH R., JONES NORMAN, BERLINER ERNST, 1942. The demonstration of pneumococcal antigen in tissues by the use of fluorescent antibody. J. Immunol. $45,159-170$.

CURTIS A. S., 1964. The mechanism of adhesion of cells to glass. a study by interference re flection microscopy. J. Cell Biol. 20, 199-215.

DANUSER G., WATERMAN-STORER C. M., 2006. Quantitative fluorescent speckle microscopy of cytoskeleton dynamics. Annu. Rev. Biophys. Biomol. Struct. 35, 361-387.

Delgado-Álvarez D. L., CAllejas-Negrete O. A., Gómez N., Freitag M., Roberson R. W., SMITH L. G., MOURIÑO-PÉREZ R. R., 2010. Visualization of F-actin localization and $d y$ namics with live cell markers in Neurospora crassa. Fungal Genet. Biol. 47, 573-586.

Dembo M., Oliver T., ISHIHARA A., JACOBSON K., 1996. Imaging the traction stresses exerted by locomoting cells with the elastic substratum method. Biophys. J. 70, 2008-2022. 
ELLINGER P., HIRT A., 1929. Mikroskopische Untersuchungen an lebenden Organen. Z. Anat. Entwicklungsgesch. 90, 791-802.

FOlKer E. S., BAKER B. M., GOODSON H. V, 2005. Interactions between CLIP-170, tubulin, and microtubules: implications for the mechanism of Clip-170 plus-end tracking behavior. Mol. Biol. Cell 16, 5373-5384.

Franck C., Maskarinec S. A., TirRell D. A., RaviCHANDRAN G., 2011. Three-dimensional traction force microscopy: a new tool for quantifying cell-matrix interactions. PLoS One 6, e17833.

GAlfRE G., MilsteIN C., 1981. Preparation of monoclonal antibodies: strategies and procedures. Methods Enzymol. 73, 3-46.

Geisler N., PotschKa M., WeBer K., 1986. Are the terminal domains in intermediate filaments organized as octameric complexes? Reevaluation of a recent suggestion. J. Ultrastruct. Mol. Struct. Res. 94, 239-245.

GuizetTi J., SCHERMElleH L., MÄNTLER J., MAAR S., POSER I., LEONHARDT H., MÜLLER-REICHERT T., Gerlich D. W., 2011. Cortical constriction during abscission involves helices of ES CRT-III-dependent filaments. Science 331, 1616-1620.

Hanna S., Miskolci V., Cox D., Hodgson L., 2014. A new genetically encoded single-chain biosensor for Cdc42 based on FRET, useful for live-cell imaging. PLoS One 9, e96469.

HARRIS A. K., WILD P., STOPAK D., 1980. Silicone rubber substrata: a new wrinkle in the study of cell locomotion. Science 208, 177-179.

HiND L. E, DEMBO M., HAMMER D. A., 2015. Macrophage motility is driven by frontal-towing with a force magnitude dependent on substrate stiffness. Integr. Biol. 7, 447-453.

Hochreiter B., GARCIA A. P., SCHMID J. A., 2015. Fluorescent proteins as genetically encoded FRET biosensors in life sciences. Sensors 15, 26281-26314.

IP W., FISCHMAN D. A., 1979. High resolution scanning electron microscopy of isolated and in situ cytoskeletal elements. J. Cell Biol. 83, 249-254.

ITOH R. E., Kurokawa K., OHBa Y., YoshizaKi H., MochizUKI N., MATsUdA M., 2002. Activation of rac and cdc42 video imaged by fluorescent resonance energy transfer-based single-molecule probes in the membrane of living cells. Mol. Cell. Biol. 22, 6582-6591.

JAY D. G., 1988. Selective destruction of protein function by chromophore-assisted laser inactivation. Proc. Natl. Acad. Sci. USA 85, 54545458.

Kanchanawong P., Shtengel G., Pasapera A. M., RAMKO E. B., DAVIDSON M. W., HESS H. F., WATERMAN C. M., 2010. Nanoscale architecture of integrin-based cell adhesions. Nature 468, 580-584.

KÖHLER G., Milstein C., 1975. Continuous cultures of fused cells secreting antibody of predefined specificity. Nature 256, 495-497.

KUKULSKI W., SCHORB M., WELSCH S., PICCO A., KAKSONEN M., BRIGGS J. A. G., 2011. Correlated fluorescence and $3 D$ electron microscopy with high sensitivity and spatial precision. J. Cell Biol. 192, 111-119.

LAZARIDES E., WeBER K., 1974. Actin antibody: the specific visualization of actin filaments in non-muscle cells. Proc. Natl. Acad. Sci. USA 71, 2268-2272.

LiU J., Wang Y., GoH W. I., GOH H., Baird M. A., Ruehland S., TEO S., BATE N., CRITChley D. R., DAVIDSON M. W., KANCHANAWONG P., 2015. Talin determines the nanoscale architec- ture of focal adhesions. Proc. Natl. Acad. Sci. USA 112, E4864-E4873.

LYNEN F., WIELAND U., 1938. Über die Giftstoffe des Knollenblätterpilzes. IV. Justus Liebig's Ann. der Chemie 533, 93-117.

MaRTin K., REIMANN A., FRITZ R. D., RYU H., JEON N. L., PERTZ O., 2016. Spatio-temporal co-ordination of RhoA, Rac1 and Cdc42 activation during prototypical edge protrusion and retraction dynamics. Sci. Rep. 6, 21901.

MCKinNey S. A., MuRPhy C. S., HAZElWOOD K. L., Davidson M. W., LOOGER L. L., 2009. A bright and photostable photoconvertible fluorescent protein. Nat. Methods 6, 131-133.

MelaK M., Plessner M., Grosse R., 2017. Actin visualization at a glance. J. Cell Sci. 130, 525-530.

MURATA K., WOLF M., 2018. Cryo-electron microscopy for structural analysis of dynamic biological macromolecules. Biochim. Biophys. Acta 1862, 324-334.

Muroyama A., LECHLER T., 2017. A transgenic toolkit for visualizing and perturbing microtubules reveals unexpected functions in the epidermis. Elife 6, e29834.

NAGASAKI A., KIJIMA S. T., YUMOTO T., IMAIZUMI M., YAMAgishi A., KIM H., NAKAMURA C., UYEDA T. Q. P., 2017. The position of the GFP Tag on actin affects the filament formation in mammalian cells. Cell Struct. Funct. 42, 131140.

POMORSKI P., 2015. Nagroda nobla $z$ chemii $z a$ rok 2014: za "Opracowanie metod superrozdzielczych $w$ mikrosko pii fluorescencyjnej", Eric Betzig, William Moerner i Stefan Hell. Kosmos 64, 203-209.

POMORSKI P., WATSON J. M., HASKILL S., JACOBsoN K. A., 2004. How adhesion, migration, and cytoplasmic calcium transients influence interleukin-1beta mRNA stabilization in human monocytes. Cell Motil. Cytoskeleton 57, 143157.

POMORSKI P., KRZEMIŃSKI P., WASIK A., WIERZBICKA K., BARAŃSKA J., KŁOPOCKA W., 2007. Actin dynamics in Amoeba proteus motility. Protoplasma 231, 31-41.

RAJFUR Z., ROY P., OTEY C., ROMER L., JACOBSON K., 2002. Dissecting the link between stress fibres and focal adhesions by CALI with EGFP fusion proteins. Nat. Cell Biol. 4, 286-293.

RIEDL J., 2010. Development and characterization of Lifeact - a versatile marker for the visualization of F-actin. Praca doktorska, Electronische Hochschulschriften, Monachium.

SCHEELE R. B., BORISY G. G., 1978. Electron microscopy of metal-shadowed and negatively stained microtubule protein. Structure of the $30 \mathrm{~S}$ oligomer. J. Biol. Chem. 253, 28462851.

Schneider G., Nieznanski K., Jozwiak J., SlomNICKI L.P., REDOWICZ M.J., FILIPEK A., 2010. Tubulin binding protein, CacyBP/SIP, induces actin polymerization and may link actin and tubulin cytoskeletons. Biochim. Biophys. Acta 1803, 1308-1317.

SEKAR R. B., PERIASAMY A., 2003. Fluorescence resonance energy transfer (FRET) microscopy imaging of live cell protein localizations. J. Cell Biol. 160, 629-633.

ShaO S., XIANG C., QIN K., UR Rehman AZIZ A., LIAO X., LIU B., 2017. Visualizing the spatiotemporal map of Rac activation in bovine aortic endothelial cells under laminar and disturbed flows. PLoS One 12, e0189088.

SHIMOMURA O., JOHNSON F. H., SAIGA Y., 1962. Extraction, purification and properties of ae- 
quorin, a bioluminescent protein from the luminous hydromedusan, Aequorea. J. Cell. Comp. Physiol. 59, 223-239.

Shtengel G., Galbraith J. A, Galbraith C. G. LipPINCOTT-SCHWARTZ J., GILlETTE J. M., MANLEY S., SOUGRAT R., WATERMAN C. M., KANCHANAWONG P., DAVIDSON M. W., FETTER R. D., HESS H. F., 2009. Interferometric fluorescent super-resolution microscopy resolves $3 D$ cellular ultrastructure. Proc. Natl. Acad. Sci. USA 106, 3125-3130.

SLIOGERYTE K., THORPE S. D., WANG Z., THOMPSON C. L., Gavara N., Knight M. M., 2016. Differential effects of LifeAct-GFP and actin-GFP on cell mechanics assessed using micropipette aspiration. J. Biomech. 49, 310-317.

SviTKINA T., 2009. Imaging cytoskeleton components by electron microscopy. Methods Mol. Biol. 586, 187-206.

SVITKINA T. M., BORISY G. G., 1999. Arp $2 / 3 \mathrm{com}-$ plex and actin depolymerizing factor/cofilin in dendritic organization and treadmilling of actin filament array in lamellipodia. J. Cell Biol. 145, 1009-1026.

SZCZESNA E., KASPRZAK A. A., 2016. Insights into the process of EB1-dependent tip-tracking of kinesin-14 Ncd. The role of the microtubule Eur. J. Cell Biol. 95, 521-530.

TURGaY Y., MEDALIA O., 2017. The structure of lamin filaments in somatic cells as revealed by cryo-electron tomography. Nucleus 8, 475481.

VANDEKERCKHOVE J., DEBOBEN A., NASSAL M., WIELAND T., 1985. The phalloidin binding site of F-actin. EMBO J. 4, 2815-2818.

VERSCHUEREN H., 1985. Interference reflection microscopy in cell biology: methodology and applications. J. Cell Sci. 75, 279-301.

VOORTMAN L., N. VAN DER VEEKEN, J. HOOGENBOOM, S. V. DEN HOEDT. 2014. Sample preparation for integrated correlative light and elec- tron microscopy. www.researchgate.net/publication/271210667_Sample_Preparation_for_Integrated_Correlative_Light_and_Electron_Microscopy

WATERMAN-Storer C. M., SAlmon E. D., 1997. Actomyosin-based retrograde flow of microtubules in the lamella of migrating epithelial cells influences microtubule dynamic instability and turnover and is associated with microtubule breakage and treadmilling. J. Cell Biol. 139, 417-434.

WATERMAN-STORER C. M., SAlMON E. D., 1998. How microtubules get fluorescent speckles. Biophys. J. 75, 2059-2069.

WATERMAN-STORER C. M., Desai A., Bulinski J. C., SALMON E. D., 1998. Fluorescent speckle microscopy, a method to visualize the dynamics of protein assemblies in living cells. Curr. Biol. 8, 1227-1230.

WeHland J., Osborn M., Weber K., 1977. Phalloidin-induced actin polymerization in the cytoplasm of cultured cells interferes with cell locomotion and growth (microfilaments/microtubules/tonofilaments/movement/immunofluorescence microscopy). 74, 5613-5617.

Weiger M. C., Wang C.-C., Krajcovic M., MelVIN A. T., RHODEN J. J., Haugh J. M., 2009. Spontaneous phosphoinositide 3-kinase signaling dynamics drive spreading and random migration of fibroblasts. J. Cell Sci. 122, 313323.

WePF R., Amrein M., Burklit U., Gross N. Z., 1991. Platinum/iridium/carbon: a high-resolution shadowing material for TEM, STM and SEM of biological macromolecular structures. J. Microsc. 163, 51-64.

Wulf E., Deboben A., Bautz F. A., Faulstich H., WIELAND T., 1979. Fluorescent phallotoxin, a tool for the visualization of cellular actin. Proc. Natl. Acad. Sci. USA 76, 4498-4502.

Kosmos Vol. 67, 1, 219-232, 2018

\section{NATALIA NOWAK ${ }^{1}$, PAWEe POMORSKI ${ }^{2,3}$}

${ }^{1}$ Laboratory of Imaging Tissue Structure and Function, Neurobiology Center, ${ }^{2}$ Laboratory of Molecular Basis of Cell Motility, Department of Biochemistry, ${ }^{3}$ Multimodal Laboratory of Cell Adhesion and Motility, NanoBioGeo Consortium, Nencki Institute of Experimental Biology PAS, 3 Pasteur Str., 02-093 Warsaw, E-mail: p.pomorski@nencki.gov.pl

\section{MICROSCOPY TECHNIQUES FOR CYTOSKELETON RESARCH}

\section{Summary}

Cytoskeleton is basically a network of protein polymers, but it also contains thousands of motor, regulatory and scaffolding proteins that interact with this network. Discoveries related to the cytoskeleton were strictly connected to the development of microscopy techniques used to observe the cytoskeletal structures. At first, the imaging involved only unspecific, very simple staining of fixed material. Then, the methods evolved into advanced structural microscopy, which enabled accurate detection of specific cytoskeletal proteins, their physiological status, and interactions with loosely bound membrane and cytoplasmic proteins. Today, it is possible not only to visualize the structure and function of the cytoskeleton with better spatial resolution but also to perform the imaging in vivo on live biological specimens. On the other hand, one should also notice that observations of the stable, well defined cytoskeletal structures from their very discovery have continuously stimulated the progress in the microscopy field.

Keywords: cytoskeleton, electron microscopy, immunocytochemistry, molecular probes, optical microscopy, superresolution microscopy 